\title{
HIGH HEART RATE AS A POTENTIAL RISK FACTOR FOR DEVELOPMENT OF CARDIOVASCULAR DISEASES IN WOMEN WITH RHEUMATOID ARTHRITIS
}

\author{
D.S. Novikova1*, T.V. Popkova1, A.N. Gerasimov², A.V. Volkov1', E.L. Nasonov \\ ${ }_{1}^{1}$ Research Institute of Rheumatology. Kashirskoie shosse 34/a, Moscow, 115522 Russia \\ 2I.M. Sechenov First Moscow State Medical University. Trubetskaya ul. 8-2, Moscow, 119991 Russia
}

\author{
High heart rate as a potential risk factor for development of cardiovascular diseases in women with rheumatoid arthritis \\ D.S. Novikova1*, T.V. Popkova1 ${ }^{1}$ A.N. Gerasimov², A.V. Volkov', Ye.L. Nasonov' \\ 1 Research Institute of Rheumatology. Kashirskoie shosse 34/a, Moscow, 115522 Russia \\ 2I.M. Sechenov First Moscow State Medical University. Trubetskaya ul. 8-2, Moscow, 119991 Russia
}

\begin{abstract}
Aim. To study relationship between heart rate (HR) and traditional risk factors for cardiovascular diseases (TRF for CVD), subclinical structural and functional changes in the heart and vessels, as well as the activity and severity of rheumatoid inflammation in women with rheumatoid arthritis (RA).

Material and methods. A total of 291 female patients less than 60 years of age with a definite diagnosis of RA were examined. The control group consisted of 125 women without rheumatic diseases. Aside from clinical symptoms, activity and severity level of RA, the presence of main TRF for CVD were assessed, $24 \mathrm{~h}$ Holter ECG monitoring (24-h ECG), duplex scanning of common carotid arteries, transthoracic echocardiography were performed and the serum levels of inflammatory markers were determined.

Results. RA patients compared with the control group women had higher values of minimum ( $52.3 \pm 0.4$ vs $47.5 \pm 0.4 ; p<0.001)$ and mean $(78.5 \pm 0.5$ vs $75.5 \pm 0.5 ; p<0.001) \mathrm{HR}$ accord ing to 24-h ECG, after adjustment for main TRF for CVD (age, arterial hypertension, menopause, levels of total cholesterol, triglycerides, high density lipoprotein cholesterol). Accelerated HR in RA directly correlated with an increased joint functional disability index - HAQ, RA severity index, the level of inflammatory markers and administration of leflunomide after adjustment for age $(p<0.05)$. Patients with $H R \geqslant 86$ beats per minute compared with RA patients with values of HR $\leqslant 71$ beats per min had lower total cholesterol $(5.84 \pm 0.13$ vs $5.11 \pm 0.17 ; p=0.001)$ and low density lipoprotein cholesterol levels ( $4.06 \pm 0.13$ vs $3.28 \pm 0.18 ; p=0.001)$, longer duration, higher activity (Visual Analog Pain Scale, DAS28, extra-articular manifestations of RA, concentration of proinflammatory markers) and severity level of RA (severity index, HAQ, radiological stage III/IV), as well as higher percentage of left ventricular diastolic dysfunction (LVDD) after adjustment for age.

Conclusion. According to 24-h ECG, an increase in mean HR values in women with RA is associated with activity, severity of rheumatoid inflammation and LVDD. Prospective studies are needed to determine the role of accelerated HR as a risk factor for development of CVD and the feasibility of preventive measures creation aimed to lower HR to prevent cardiovascular events in RA.

Key words: rheumatoid arthritis, heart rate, risk factor for development of cardiovascular diseases
\end{abstract}

Rational Pharmacother. Card. 2012;8(5):636-646

Высокая частота сердечных сокращений как потенциальный фактор риска развития сердечно-сосудистых заболеваний у женщин с ревматоидным артритом
Д.С. Новикова1*, Т.В. Попкова1, А.Н. Герасимовㄹ, А.В. Волков 1, Е.Л. Насонов1
1 Научно-исследовательский институт ревматологии РАМН. 1 15522, Москва, Каширское шоссе, 34/а
2 Первый Московский государственный медицинский университет имени И.М. Сеченова. 119991, Москва, ул. Трубецкая, 8 стр. 2

Цель. Изучить характер взаимосвязи частоты сердечных сокращений (ЧСС) с традиционными факторами риска сердечно-сосудистых заболеваний (ТФР ССЗ), субклиническими структурно-функциональными изменениями сердца и сосудов, а также активностью и тяжестью ревматоидного воспаления у женщин с ревматоидным артритом (РА).

Материал и методы. Обследовали 291 пациентку с достоверным диагнозом РА в возрасте до 60 лет. В контрольную группу были включены 125 женщин без ревматических заболеваний. Помимо клинических проявлений, степени активности и тяжести РА, оценивали наличие основных ТФР ССЗ, проводили холтеровское мониторирование ЭКГ (ХМ-ЭКГ), дуплексное сканирование общих сонных артерий, трансторакальную эхокардиографию и определение уровней сывороточных маркеров воспаления.

Результаты. Пациентки с РА отличались от женщин контрольной группы более высокими значениями минимальной $(52,3 \pm 0,4$ против 47,5 $\pm 0,4 ;$ р $<0,001)$ и средней $(78,5 \pm 0,5$ против 75,5 $\pm 0,5 ; p<0,001$ ) ЧСС по данным ХМ-ЭКГ с учётом поправки на основные ТФР ССЗ (возраст, артериальная гипертензия, менопауза, концентрация общего холестерина, триглицеридов, холестерина липопротеинов высокой плотности). Повышение ЧСС при РА прямо коррелировало с увеличением индекса функциональной недостаточности суставов HAQ, индекса тяжести РА, уровня воспалительных маркеров и приёмом лефлуномида с учётом поправки на возраст (р<0,05). Пациентки с ЧСС $\geqslant 86$ уд/мин отличались от больных РА со значениями ЧСС $\leqslant 71$ уд/мин более низкой концентрацией общего холестерина $(5,84 \pm 0,13$ против $5,11 \pm 0,17 ;$ р $=0,001)$ и холестерина липопротеинов низкой плот-

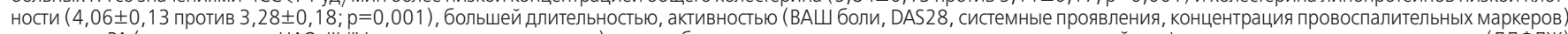
и тяжестью PA (индекс тяжести, НAQ, III/IV рентгенологическая стадия), а также более высоким процентом выявления дистолической дисфункции миокарда левого желудочка (ДДФЛЖ) с учётом поправки на возраст.

Заключение. У женщин С РА увеличение средней ЧСС по данным ХМ-ЭКГ ассоциируется с активностью, тяжестью ревматоидного воспаления и наличием ДДФЛЖ. Необходимо проведение проспективных исследований для определения роли повышенной ЧСС как фактора риска развития ССЗ и целесообразности разработки профилактических мероприятий, направленных на снижение ЧСС с целью предотвращения сердечно-сосудистых осложнений при РА.

Ключевые слова: ревматоидный артрит, частота сердечных сокращений, фактор риска развития сердечно-сосудистых заболеваний.

РФК 2012;8(5):636-646

*Corresponding author (Автор, ответственный за переписку): diananovikova75@yandex.ru

Rheumatoid arthritis (RA) is a chronic autoimmune disease with a confirmed high cardiovascular risk. The meta-analysis of 17 prospective studies shows the increase in cardiovascular mortality rate in RA by $60 \%$ as compared with general population [1] due to higher risk of myocardial infarction and stroke [2]. The

\section{Authors' information:}

Diana S. Novikova - PhD, MD, Senior Researcher, Laboratory of Functional and Ultrasound Diagnostics, Research Institute of Rheumatology

Tatyana V. Popkova - PhD, MD, Head of Laboratory of Systemic Rheumatic Diseases, the same institute

Andrey N. Gerasimov - PhD, Head of Department of Medical Informatics and Statistics, I.M.Sechenov First Moscow State Medical University

Alexander V. Volkov - PhD, MD, Head of Laboratory of Functional and UItrasound Diagnostics, Research Institute of Rheumatology

Eugeny L. Nasonov - PhD, MD, Professor, Academician of Russian Academy of Medical Sciences, Director of Research Institute of Rheumatology
Ревматоидный артрит (РА) является хроническим аутоиммунным заболеванием с доказано высоким кардиоваскулярным риском. Мета-анализ 17 проспективных исследований свидетельствует о повышении уровня сердечнососудистой летальности при РА на 60\% по сравнению с общей популяцией [1], что обусловлено увеличением риска
Сведения об авторах

Новикова Диана Сергеевна - К.М.Н., С.Н.С. лаборатории функциональной и ультразвуковой диагностики НИИР РАМН

Попкова Татьяна Валентиновна - Д.М.Н., руководитель лаборатории системных ревматических заболеваний НИИР РАМН

Герасимов Андрей Николаевич - Д.ф.-М.Н., заведующий кафедрой медицинской информатики и статистики Первого МГМУ им. И.М. Сеченова

Волков Александр Витальевич - К.м.Н., заведующий лабораторией функциональной и ультразвуковой диагностики НИИР РАМН Насонов Евгений Львович - Д.м.Н., профессор, академик РАМН, директор НИИР РАМН 
existing standard methods for the determination of cardiovascular diseases (CVD) probability are based on diagnosis and evaluation of their traditional risk factors (TRF). However, the majority of cardiovascular accidents develop in RA patients with a low or moderate risk according to TRF [3], therefore, the search for other predictors of cardiovascular events (CVE) development is of current interest. Systemic inflammation in RA causes dyslipidemia, carbohydrate metabolism disorders, endothelium dysfunction, the start of cardiovascular remodeling, and increase in prothrombogenic potential [4], that, in its turn, can negatively influence the function of the autonomic nervous system promoting hypersympathicotonia [5-7]. Accelerated resting heart rate $(H R)$ can reflect an increased activity of sympathetic and/or decreased activity of parasympathetic nervous system [8]. Resting HR over 80-85 beats per min is associated with a risk of arterial hypertension $(\mathrm{AH})$ and atherosclerosis development and is an independent predictor of CVE in subjects with and without CVD symptoms [9-14]. Aronow W. et al. have revealed relation between cardiovascular mortality and $\mathrm{HR}$ recorded during $24 \mathrm{~h}$ Holter ECG monitoring (24-h ECG) [15]. Accelerated HR according to 24-h ECG is associated with a higher concentration of proinflammatory markers in blood serum of middle-aged and elderly subjects without clinical signs of CVD [16]. Hypersympathicotonia and inflammation are likely to potentiate each other, by that promoting the development of atherosclerosis and CVE.

The aim of our study was to investigate relationship between HR and TRF for CVD, subclinical structural and functional changes in the heart and vessels, as well as the activity and severity of rheumatoid inflammation in women with RA.

\section{Material and methods}

The study was presented within the framework of the program "Cardiovascular disorders and atherosclerosis in rheumatic diseases" conducting by the Research institute of rheumatology. The study included 291 women with a definite diagnosis of RA established according to criteria of the American College of Rheumatologists (ACR, 1987) [17]. The examination was carried out in compliance with Recommendations by the Association of Rheumatologists of Russia [18]. The control group included 125 women without rheumatic diseases, who did not conform to the exclusion criteria (the employees of institute). Exlusion criteria were age $>60$ years, ischemic heart disease (IHD: angina pectoris, history of myocardial infarction), clinical symptoms of chronic heart failure (CHF) functional class II-IV, history of cerebral stroke, the patients with diabetes mellitus, valvular heart disease, obesi- развития инфаркта миокарда и инсульта [2]. Существующие стандартные методы определения вероятности развития сердечно-сосудистых заболеваний (ССЗ) основаны на выявлении и оценке традиционных факторов риска (ТФР) их развития. Однако большинство случаев сердечно-сосуди стых катастроф развивается у больных РА с низким или умеренным риском согласно ТФР [3], поэтому актуален поиск других предикторов возникновения сердечно-сосудистых осложнений (ССО). При РА системное воспаление приводит к развитию дислипидемии, нарушению углеводного обмена, дисфункции эндотелия, запуску ремоделирования сердечно-сосудистой системы, повышению протромбогенного потенциала [4], что, в свою очередь, может негативно влиять на работу автономной нервной системы, способствуя гиперсимпатикотонии [5-7]. Высокая ЧСС в покое может отражать повышенную активность симпатической и/или сниженную активность парасимпатической нервной системы [8]. чСС более 80-85 уд/мин в состоянии покоя связана с риском развития артериальной гипертонии (АГ), атеросклероза и является независимым предиктором ССО как у лиц без симптомов СС3, так и с наличием таковых [9-14]. Aronow W. и соавт. обнаружили связь между сердечно-сосудистой смертностью и ЧСС, зарегистрированной при холтеровском мониторировании ЭКГ (ХМ-ЭКГ) [15]. Увеличение ЧСС по данным ХМ-ЭКГ ассоциируется с повышением концентрации провоспалительных маркеров в сыворотке крови у лиц среднего и пожилого возраста без клинических признаков ССЗ [16]. Возможно, гиперсимпатикотония и воспаление потенцируют друг друга, тем самым, ускоряя развитие атеросклероза и ССО.

Целью нашего исследования явилось изучение характера взаимосвязи ЧСС с ТФР ССЗ, субклиническими структурнофункциональными изменениями сердца и сосудов, а также активностью и тяжестью ревматоидного воспаления у женщин с РА.

\section{Материалы и методы}

Работа выполнялась в рамках программы Научно-исследовательского института ревматологии «Кардиоваскулярные нарушения и атеросклероз при ревматических заболеваниях». В исследование включена 291 женщина с достоверным диагнозом РА, установленным согласно критериям Американского колледжа ревматологов (ACR, 1987) [17]. Обследование проведено согласно Рекомендациям Ассоциации ревматологов России [18]. Контрольную группу составили 125 женщин без ревматических заболеваний, не попадающие под критерии исключения (сотрудники НИИР РАМН). В исследование не включались лица старше 60 лет, с ишемической болезнью сердца (ИБС: стенокардия, перенесённый инфаркт миокарда), клиническими проявлениями хронической сердечной недостаточности (XCH) IIIV ФК, перенесшие мозговой инсульт, пациенты с сахарным диабетом, клапанными пороками сердца, ожирением 34 степени, язвенной болезнью желудка и двенадцати- 
ty class III-IV, gastric and duodenal ulcers, oncological diseases, clinically significant thyroid diseases. To take part in the study, all participants have signed voluntary informed consent. The study protocol was approved by the local Ethics committee.

Prior to the primary investigation of RA patients and control subjects at the first phase there was a week of "washout period" in case the participants had received $\beta$-adrenoblockers, angiotensin-converting enzyme inhibitors, calcium channel blocker, statins and sedatives. A cross-sectional study included the anamnestic data survey; anthropometric measurements including height, weight and body mass index (BMI); "office" blood pressure (BP) measurement by standard method, biochemical blood analysis including lipid profile with the index of atherogenicity calculation, and fasting venous blood glucose. To determine the total risk of development of CVE, the SCORE scale was used [19]. 24-h ECG was conducted with the use of a 3-channel monitor (Astrocard ${ }^{\circledR}$ - Holtersystem, ZAO "Meditech", Russia). To reveal subclinical forms of atherosclerosis, duplex scanning of common carotid arteries was undertaken using the system "Voluson 730 Expert" (Austria) to measure the intimamedia thickness (IMT) on two sides in three areas of carotid arteries (right and left common, internal and the carotid arteries bulb) and to calculate a mean value of IMT on the left and on the right. The measurements were made along the posterior wall of the artery at a site with no discrete plaques. IMT $<0.9 \mathrm{~mm}$ was considered as standard. IMT $\geqslant 1.2 \mathrm{MM}[20]$ was considered as ASP. IMT>0.9 mm and/or presence of ASP were considered as atherosclerosis of carotid arteries. RA patients also underwent the standard transthoracic echocardiography in M-, B- and Doppler modes with calculation of the left ventricular myocardial mass index (LVMMI) [21] and assessment of LV diastolic function [22].

The statistical analysis of results was made with software complex Epilnfo 5.0 recommended for use in medico-biological applications. To describe the distribution of analyzed indices, the incidence rate of discrete variables or parameters for continuous were calculated using the $M \pm m$ standard presentation, where $M$ is an arithmetic mean, and $m$ is a statistical error [23]. The significant difference between groups by quantitative signs was assessed using Student's t-test. To check the correct use of parametric statistics methods, the types of distributions of variables were analyzed. In case of their noncompactness, the analogous nonparametric methods were used. When the incidence rate of indices between groups was compared, $\chi^{2}$ criterion was used. To reveal the degree of correlation between indices, the Spearman's перстной кишки, онкологическими заболеваниями, клинически значимыми заболеваниями щитовидной железы. Все участники подписали добровольное информированное согласие на участи в исследовании. Протокол исследования одобрен локальным Этическим комитетом.

Первичному обследованию больных РА и лиц контрольной группы на первом этапе предшествовал недельный период «вымывания препаратов» в случае, если обследуемые получали $\beta$-адреноблокаторы, ингибиторы ангиотензинпревращающего фермента, блокаторы медленных кальциевых каналов, статины и препараты с седативным эффектом. Проведено одномоментное исследование, включающее оценку анамнестических данных; антропометрическое исследование с измерением роста, веса и вычислением индекса массы тела (ИМТ); измерение «офисного» АД по стандартной методике, биохимическое исследование крови [липидный спектр с вычислением индекса атерогенности (ИА), глюкоза венозной крови натощак]. Для определения суммарного риска развития ССО использована шкала SCORE [19]. ХM-ЭКГ проводилось с использованием 3-х канального монитора (Astrocard ${ }^{\circledR}$-Holtersystem, ЗАО «Медитек», Россия). Для выявления субклинических форм атеросклероза проводилось дуплексное сканирование общих сонных артерий на аппарате «Voluson 730 Expert» (Австрия) с измерением толщины комплекса интима-медиа (ТИМ) с двух сторон в трех участках сонных артерий (правой и левой общей, внутренней и луковице сонных артерий) с вычислением средней ТИМ слева и справа. Измерения проводили по задней стенке артерии вне зоны локализации атеросклеротической бляшки (АСБ). Нормальной считали ТИМ<0,9 мм. За АСБ принимали увеличение ТИМ $\geqslant 1,2$ мм [20]. За наличие атеросклероза сонных артерий принимали увеличение ТИМ>0,9 мм и/или присутствие АСБ. Пациенткам с РА также выполняли стандартную трансторакальную эхокардиографию (ЭХО-КГ) в М-, В- и Допплер-режимах с определением индекса массы миокарда левого желудочка [21] и изучением диастолической функции Лж [22].

Статистический анализ результатов проводили с помощью программного комплекса Epilnfo 5.0, рекомендованного для использования в медико-биологических приложениях. Для описания распределения анализируемых показателей рассчитывали частоты встречаемости для дискретных переменных или параметры для непрерывных, используя стандартное представление $M \pm m$, где $M$ - среднее арифметическое, $m$ - статистическая погрешность его определения [23]. Достоверность различий между группами по количественным признакам оценивалась при помощи t-критерия Стьюдента. Для поверки корректности использования методов параметрической статистики анализировали формы распределения переменных. В случае их некомпактности использовали аналогичные методы непараметрической статистики. При сравнении частоты встречаемости показателей между группами использовали критерий $\chi^{2}$. Для выявления 
Table 1. Clinical and laboratory characteristics of women with RA $(n=291)$

Таблица 1. Клинико-лабораторная характеристика женщин с PA (n=291)

\begin{tabular}{|c|c|}
\hline Indicator / Показатель & Value / Значение \\
\hline Age, years / Возраст, годы & $45.8 \pm 0.6$ \\
\hline Disease duration, months / Длительность болезни, мес & $119.2 \pm 6.4$ \\
\hline 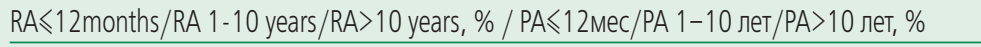 & $10 / 51 / 39$ \\
\hline Activity level (score) DAS 28, points / Степень активности DAS 28, баллы & $5.5 \pm 0.1$ \\
\hline Radiological stage: I/II; III/IV,\% / Рентгенологическая стадия:, I/II; III/IV,\% & $40.8 ; 59.1$ \\
\hline HAQ index, points / Индекс HAQ, баллы & $1.5 \pm 0.04$ \\
\hline Pain by VAPS, mm / ВАШ боли, мм & $51.9 \pm 1.1$ \\
\hline Extra-articular manifestations of RA, \% / Внесуставные проявления PA, \% & 29 \\
\hline RF: seropositive/seronegative, \% / РФ: серопозитивный/серонегативный, \% & $76 / 24$ \\
\hline $\begin{array}{l}\text { Cyclic citrullinated peptide antibodies: seropositive/seronegative, \% / } \\
\text { антитела к циклическому цитруллиновому пептиду: серопозитивный/серонегативный, \% }\end{array}$ & $78 / 22$ \\
\hline Severity index, points / Индекс тяжести, баллы & $5.45 \pm 0.17$ \\
\hline Intake of GC, \% / Применение ГК, \% & 51 \\
\hline Age of GC therapy commencement, years / Возраст начала ГК, лет & $43.2 \pm 0.9$ \\
\hline Cumulative dose of GC, g / Кумулятивная доза ГК, г & $12.7 \pm 1.0$ \\
\hline GC dose at the moment of examination, g / Доза ГК на момент обследования, г & $8.2 \pm 0.3$ \\
\hline $\mathrm{BAID}, \% / Б$ БПВП, $\%$ & 76 \\
\hline $\begin{array}{l}\text { Methotrexate/leflunomide/hydroxychloroquine/sulfasalazin, \% / } \\
\text { Метотрексат/лефлуномид/гидроксихлорохин/сульфасалазин, \% }\end{array}$ & $59 / 21 / 7 / 7$ \\
\hline Other BAID,\% / Другие БПВП,\% & 6 \\
\hline NSAID, $\% / H \Pi B \Pi, \%$ & 94.2 \\
\hline Leukocytes, 109 / / Лейкоциты, 109/л & $8.4 \pm 0.2$ \\
\hline Platelets, 109/I / Тромбоциты, 109/л & $344.6 \pm 6.7$ \\
\hline $\mathrm{CRP}, \mathrm{mg} / \mathrm{l} / \mathrm{CPБ}, \mathrm{мг} / л$ & $28.6 \pm 1.7$ \\
\hline $\mathrm{ESR}, \mathrm{mm} / \mathrm{h} / \mathrm{CO}, \mathrm{Mm} / \mathrm{4}$ & $35.5 \pm 1.3$ \\
\hline $\begin{array}{l}\text { Data are presented as } M \pm m \text {, unless otherwise specified } \\
\text { Данные представлены как } M \pm m \text {, если не указано иначе }\end{array}$ & \\
\hline
\end{tabular}

rank correlation coefficient ( $r$ ) was calculated. When needed to analyze a real significance of a risk factor with regard to some clinical symptoms the expectation of which essentially depended on the age (or the presence of other factors), we calculated and analyzed partial correlation coefficients adjusted for age (or the presence of other factor) [24]. The differences between values were significant at $p<0.05$.

\section{Results}

The clinical characteristics of RA patients are demonstrated in Table 1.

The RA patients were older, $\mathrm{AH}$, menopause were recorded more often; the level of triglycerides (TG), index of atherogenicity, systolic BP (SBP), diastolic $\mathrm{BP}$ (DBP), BMI, and SCORE index were higher, but the level of high density lipoprotein cholesterol (HDLC) was lower than this in patients of the control group (Table 2). After adjustment for age, in RA women as compared with women in control group, differences in the levels of TG, HDLC, IA, the incidence rate of $\mathrm{AH}$ and menopause remained significant. Also after adjustment for age, the levels of total cholesterol (TCh) and low density lipoprotein cholesterol (LDLC) in степени взаимосвязи между показателями рассчитывали коэффициент корреляции Спирмена (r). В том случае, когда нужно было проанализировать реальную значимость фактора риска по отношению к некоторому клиническому проявлению, вероятность которого существенно зависела от возраста (или наличия других факторов), рассчитывали и анализировали коэффициенты частной корреляции под контролем возраста (или наличия другого фактора) [24]. Достоверными считали различия показателей при р<0,05.

\section{Результаты}

Клиническая характеристика пациенток с РА представлена в табл. 1.

Пациентки с РА были старше по возрасту, у них чаще регистрировалась АГ, менопауза, был выше уровень триглицеридов (ТГ), ИА, систолическое АД (САД), диастолическое АД (ДАД), индекс массы тела (ИМТ), индекс SCORE, а концентрация холестерина липопротеинов высокой плотности (ХС ЛПВП) ниже, чем в у больных контрольной группы (табл. 2). При поправке на возраст у женщин с РА по сравнению с женщинами контрольной группы сохранились достоверные различия по уровню ТГ, ХС ЛПВП, ИА, частоте встречаемости $А Г$, менопаузы. Также при поправке на возраст концентрация общего холестерина (ОХС) и холестерина ли- 
Table 2. Comparison of TRF for CVD with the value of IMT of carotid arteries in women with RA and ones of the control group Таблица 2. Сравнение ТФР ССЗ и величины ТИМ сонных артерий у женщин с РА и контрольной группы

\begin{tabular}{|c|c|c|c|c|c|c|}
\hline & $\begin{array}{l}\mathrm{RA} / \mathrm{PA} \\
(\mathrm{n}=291)\end{array}$ & $\begin{array}{c}\text { Control / Контроль } \\
(n=125)\end{array}$ & $r^{1}$ & $p^{1}$ & $r^{2}$ & $p^{2}$ \\
\hline Age, years / Возраст, годы & $45.8 \pm 0.6$ & $41.8 \pm 0.9$ & -0.177 & $<0.001$ & - & - \\
\hline TCh, mmol/l / OХС, ммоль/л & $5.65 \pm 0.08$ & $5.83 \pm 0.12$ & ns / нд & ns / нд & 0.14 & 0.01 \\
\hline TCh>5 mmol/l, \% / ОХС>5 ммоль/л, \% & 68.9 & 73.0 & ns / нд & ns / нд & 0.12 & 0.017 \\
\hline LDLC, mmol/l / ХС ЛНП, ммоль/л & $3.79 \pm 0.08$ & $3.91 \pm 0.11$ & ns / нд & ns / нд & 0.12 & 0.03 \\
\hline LDLC>3 mmol/l, \% / ХС ЛНП>3 ммоль/л, \% & 74.3 & 77.2 & ns / нд & ns / нд & 0.11 & 0.034 \\
\hline TG, mmol/l / ТГ, ммоль/л & $1.15 \pm 0.05$ & $0.81 \pm 0.06$ & -0.28 & $<0.001$ & -0.19 & $<0.001$ \\
\hline TG>1.7 mmol/l, \% / ТГ>1,7 ммоль/л, \% & 17.5 & 8.0 & -0.12 & 0.013 & -0.11 & 0.034 \\
\hline HDLC, mmol/l / ХС ЛПВП, ммоль/л & $1.36 \pm 0.03$ & $1.56 \pm 0.03$ & 0.25 & $<0.001$ & 0.24 & $<0.001$ \\
\hline $\mathrm{HDLC}<1.2 \mathrm{mmol} / \mathrm{I} /$ ХС ЛВП<1,2 ммоль $/ л$ & 38.7 & 12.8 & -0.26 & $<0.001$ & -0.27 & $<0.001$ \\
\hline IA / UA & $4.50 \pm 0.09$ & $3.90 \pm 0.10$ & -0.19 & $<0.001$ & -0.16 & $<0.001$ \\
\hline $\mid A>3 / U A>3$ & 86.5 & 76 & -0.13 & 0.01 & ns / нд & ns / Hд \\
\hline Glucose, mmol/l / Глюкоза, ммоль/л & $4.8 \pm 0.04$ & $4.8 \pm 0.05$ & ns / нд & ns / нд & ns / нд & ns / нд \\
\hline Glucose >6.0 mmol// / Глюкоза>6,0 ммоль/л & 3.3 & 3.0 & ns / нд & ns / нд & ns / нд & ns / НД \\
\hline SВР, mmHg / САД, ммрт.ст. & $128.3 \pm 1.3$ & $119.1 \pm 1.5$ & -0.15 & 0.011 & ns / нд & ns / нд \\
\hline DВP, mmHg / ДАД, мм рт.ст. & $78.2 \pm 0.8$ & $73.9 \pm 0.9$ & -0.13 & 0.018 & ns / нд & ns / нд \\
\hline $\mathrm{AH}, \% / \mathrm{AI}, \%$ & 52 & 18 & -0.32 & $<0.001$ & -0.27 & $<0.001$ \\
\hline $\mathrm{BMI}, \mathrm{kg} / \mathrm{m}^{2} /$ ИМТ, кг/M² & $25.01 \pm 0.32$ & $23.90 \pm 0.40$ & ns / нд & ns / нд & ns / нд & ns / нд \\
\hline $\mathrm{BMI} \geqslant 25 \mathrm{~kg} / \mathrm{m}^{2}, \% /$ ИМT $\geqslant 25 \mathrm{kr} / \mathrm{M}^{2}, \%$ & 41 & 29 & -0.12 & 0.02 & ns / нд & ns / НД \\
\hline Smoking, \% / Курение, \% & 17 & 16 & ns / нд & ns / нд & ns / нд & ns / нд \\
\hline Menopause, \% / Менопауза, \% & 47 & 20 & -0.26 & $<0.001$ & -0.2 & $<0.001$ \\
\hline $\begin{array}{l}\text { CVD in family history,\% / } \\
\text { Отягощённая наследственность по СС3,\% }\end{array}$ & 36 & 36 & ns / нд & ns / нд & ns / нд & ns / нд \\
\hline Hypodynamia, \% / Гиподинамия, \% & 45 & 35 & -0.14 & 0.019 & ns / нд & ns / нд \\
\hline SCORE, \% / SCORE, \% & $0.68 \pm 0.05$ & $0.39 \pm 0.05$ & -0.18 & 0.001 & ns / нд & ns / нд \\
\hline $\begin{array}{l}\text { Atherosclerosis of carotid arteries, \% / } \\
\text { Атеросклероз сонных артерий, \% }\end{array}$ & 40.5 & 28.8 & -0.16 & 0.012 & ns / нд & ns / нд \\
\hline $\begin{array}{l}\text { IMT average on the left, mm / } \\
\text { ТИМ средняя слева, мм }\end{array}$ & $0.74 \pm 0.02$ & $0.72 \pm 0.01$ & -0.13 & 0.025 & ns / нд & ns / нд \\
\hline $\begin{array}{l}\text { IMT average on the right, mm / } \\
\text { ТИМ средняя справа, мм }\end{array}$ & $0.73 \pm 0.02$ & $0.73 \pm 0.02$ & ns / нд & ns / нд & ns / нд & ns / нд \\
\hline \multicolumn{7}{|c|}{ 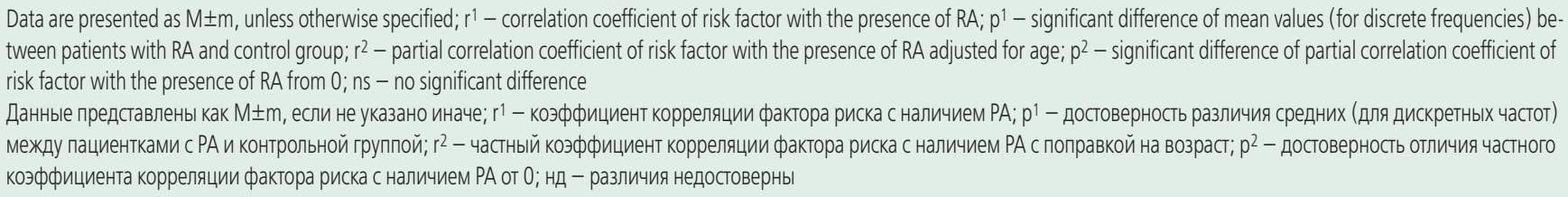 } \\
\hline
\end{tabular}

women with RA became significantly lower than in control group. After adjustment for age, the incidence of atherosclerosis of carotid arteries, the values of mean IMT on the left and on the right in women with RA and of control group did not differ significantly. Thus, RA patients unlike women of control group had a higher incidence of $\mathrm{AH}$, menopause, dyslipidemia without significant differences in frequency of subclinical atherosclerotic lesions of carotid arteries.

Women with RA had higher minimum and mean values of $H R$, however, maximum values of $H R$ were lower in comparison with those in control group (Table 3). Owing to differences in some TRF for CVD in women with RA and control group, HR values were compared after adjustment for these factors. After попротеинов низкой плотности (ХС ЛПНП) у женщин с РА стала значимо ниже, чем в контроле. Частота встречаемости атеросклероза сонных артерий, величины средней ТИМ слева и справа у женщин с РА и контрольной группы при поправке на возраст значимо не различались. Таким образом, пациентки с РА отличались от контрольной группы более высокой частотой встречаемости АГ, менопаузы, дислипидемии при отсутствии достоверных различий по частоте выявления субклинического атеросклеротического поражения сонных артерий.

У женщин с РА значения минимальной и средней ЧСС были выше, а значения максимальной ЧСС ниже по сравнению с таковыми в контрольной группе (табл. 3). В связи с различиями по ряду ТФР ССЗ между женщинами с РА и контрольной группы проведено сравнение показате- 
Table 3. Comparison of HR by 24-h ECG in women with RA and control group

Таблица 3. Сравнение ЧСС по данным ХМ-ЭКГ у женщин с РА и контрольной группы

\begin{tabular}{|c|c|c|c|c|c|c|}
\hline Indicators / Показатели & $\begin{array}{l}R A / P A \\
(n=291)\end{array}$ & $\begin{array}{c}\text { Control / Контроль } \\
(n=125)\end{array}$ & $r^{1}$ & $p^{1}$ & $r^{2}$ & $p^{2}$ \\
\hline Minimum HR, beats per min / Минимальная ЧСС, уд/мин & $52.3 \pm 0.4$ & $47.5 \pm 0.4$ & -0.34 & $<0.001$ & -0.3 & $<0.001$ \\
\hline Mean HR, beats per min / Средняя ЧСС, уд/мин & $78.5 \pm 0.5$ & $75.5 \pm 0.5$ & -0.17 & $<0.001$ & -0.2 & $<0.001$ \\
\hline Maximum HR, beats per min / Максимальная ЧСС, уд/мин & $136.4 \pm 1.0$ & $142.9 \pm 1.3$ & 0.19 & $<0.001$ & ns / нд & ns / нд \\
\hline \multicolumn{7}{|c|}{ 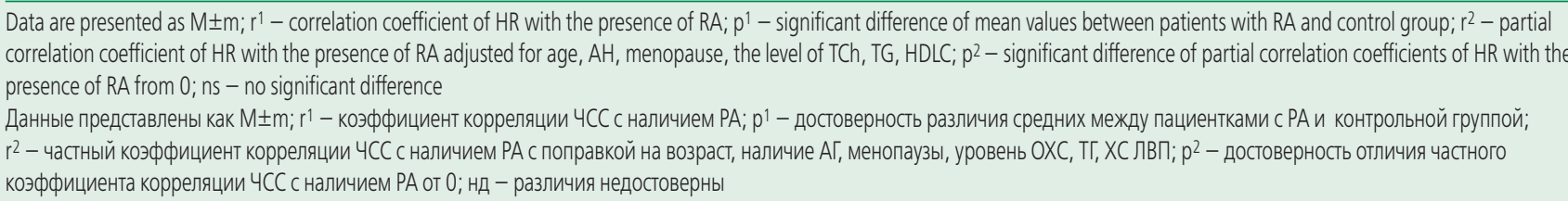 } \\
\hline
\end{tabular}

adjustment for age, $\mathrm{AH}$, menopause, levels of TCh, triglycerides, and HDLC in RA patients as compared with women of control group, differences in the level of minimum and mean HR remained significant. Thus, the women with RA show higher values of minimum and mean HR by 24-h ECG after adjustment for main TRF for CVD.

Correlation analysis data for all examined RA patients ( $n=291$ ) showed that the increased rate of mean HR negatively correlates with age, the level of TCh, LDLC, systolic BP, diastolic BP, IMT, SCORE index and the presence of $\mathrm{AH}$ and menopause (Table 4). A direct correlation of $\mathrm{HR}$ with clinical symptoms of $\mathrm{RA}$ was revealed: the presence of extra-articular manifestations of RA, severity of pain by Visual Analog Pain Scale (VAPS), HAQ (Health Assessment Questionnaire) index, severity index, laboratory markers of inflammation: the level of leukocytes, platelets, C-reactive protein (CRP), erythrocyte sedimentation rate (ESR), and administered therapy: presence of basic anti-inflammatory drugs (BAID) $(p<0.05)$. After adjustment for age, no correlation of mean HR with all TRF for CVD and SCORE was revealed except for correlation of HR with the level of SBP and DBP. After adjustment for age, the relation between the mean value of $\mathrm{HR}$ and the level of inflammatory markers, HAQ index and severity index has intensified. The association of mean HR with extra-articular manifestations of RA, pain by VAPS and the use of BAID remained. (Table 4). The correlations of mean HR with SBP and DBP lost their significance after adjustment for the level of $C$-reactive protein ( $r$ $0.09 ; p>0.2$ ). The detailed analysis of the administered BAID therapy has revealed that mean HR was significantly higher in patients receiving leflunomide $(n=47)$ as compared with patients taking other BAID $(n=175)$ or not taking BAID ( $n=69)$ : $81 \pm 0.4,77 \pm 0.4$ and $76 \pm 0.5$, respectively $(p=0.037)$. Higher mean HR was not associated with the presence of atherosclerotic lesions and the value of IMT of carotid arteries, dimensions of cardiac chambers and left ventricle mass index in women with RA. Thus, after adjustment for лей чСС с учетом поправки на эти факторы. При поправке на возраст, АГ, наличие менопаузы, концентрацию ОХС, ТГ, ХС ЛПВП у больных РА по сравнению с женщинами контрольной группы сохранились значимые различия по уровню минимальной и средней ЧСС. Таким образом, женщины с РА отличаются более высокими значениями минимальной и средней ЧСС по данным ХМ-ЭКГ с поправкой на все основные ТФР ССЗ.

Данные корреляционного анализа в целом по всем обследованным больным РА $(n=291)$ показали, что степень повышения средней ЧСС имеет обратную связь с возрасТом, уровнем ОХС, ХС ЛПНП, САД, ДАД, ИМТ, индексом SCORE и наличием АГ, менопаузы (табл. 4). Выявлена прямая корреляция ЧСС с клиническими проявлениями РА: наличием системных проявлений, выраженностью боли по визуальной аналоговой шкале (ВАШ), индексом HAQ (Health Assessment Questionnaire), индексом тяжести, лабораторными показателями воспаления: уровнем лейкоцитов, тромбоцитов, С-реактивного белка (СРБ), скорости оседания эритроцитов (СОЭ), проводимой терапией: наличием базисных противовоспалительных препаратов (БПВП) $(p<0,05)$. При поправке на возраст корреляции средней ЧСС со всеми ТФР ССЗ и SCORE не обнаружено, за исключением взаимосвязи ЧСС и уровня САД и ДАД. При поправке на возраст усилилась связь средней ЧСС с уровнем воспалительных маркеров, индексом HAQ, индексом тяжести. Сохранилась ассоциация средней ЧСС с системными проявлениями, ВАШ боли и использованием БПВП (табл. 4). Корреляции средней ЧСС с САД и ДАД теряли свою значимость при коррекции по уровню СРБ $(r-0,09 ; p>0,2)$. При детальном анализе проводимой терапии БПВП обнаружено, что средняя ЧСС была достоверно выше у больных, получающих лефлуномид ( $n=47)$, чем таковая у больных, получающих другие БПВП $(\mathrm{n}=175)$ или не получающих БПВП (n=69): $81 \pm 0,4,77 \pm 0,4$ и 76 $\pm 0,5$, соответственно $(p=0,037)$. Увеличение средней ЧСС не ассоциировалось с наличием атеросклеротического поражения и величиной ТИМ сонных артерий, размерами полостей сердца и индекса массы миокарда левого желудочка у женщин с РА. Таким образом, после поправки на возраст повышение ЧСС при РА прямо ассоциируется только с увеличением индекса 
Table 4. Correlation of mean HR with TRF for CVDs, clinical symptoms of RA, conducted therapy and inflammatory markers in women with RA

Таблица 4. Взаимосвязь средней ЧСС с ТФР ССЗ, клиническими проявлениями РА, проводимой терапией и маркерами воспаления у женщин с РА

\begin{tabular}{|c|c|c|}
\hline Indicators / Показатели & $\begin{array}{l}\text { Mean HR, beats per min }\left(r^{1}\right) / \\
\text { Средняя ЧСС, уд/мин }\left(r^{1}\right)\end{array}$ & $\begin{array}{c}\text { Mean HR, beats per min }\left(r^{2}\right) / \\
\text { Средняя ЧСС, уд/мин }\left(r^{2}\right)\end{array}$ \\
\hline Age, years / Возраст, лет & $-0.24 * *$ & ns / нд \\
\hline TCh, mmol/l / ОХС, ммоль/л & $-0.15^{* *}$ & ns / нд \\
\hline LDLC, mmol/l / ХС ЛНП, ммоль/л & $-0.17^{* *}$ & ns / нд \\
\hline SBP, mm Hg / САД, мм рт.ст. & $-0.23 * *$ & $-0.15^{*}$ \\
\hline DВР, mm Hg / ДАД, мм рт.ст. & $-0.22 * *$ & $-0.15^{*}$ \\
\hline AH, yes/no / Наличие АГ, да/нет & $-0.18^{* *}$ & ns / нд \\
\hline Menopause, yes/no / Наличие менопаузы, да/нет & $-0.17 * *$ & ns / НД \\
\hline $\mathrm{BMI}, \mathrm{kg} / \mathrm{m}^{2} /$ ИМТ, кг/M² & $-0.19 * *$ & ns / нд \\
\hline SCORE, \% / SCORE, \% & $-0.22^{* *}$ & ns / нд \\
\hline Extra-articular manifestations of RA / Системные проявления & $0.15^{*}$ & $0.15^{*}$ \\
\hline Pain by VAPS, mm / ВАШ боли, мм & $0.19 * *$ & $0.19 * *$ \\
\hline HAQ index, points / Индекс HAQ, баллы & $0.20^{* *}$ & $0.30^{* *}$ \\
\hline Severity index, points / Индекс тяжести, баллы & $0.28^{* *}$ & $0.35^{* *}$ \\
\hline Basic anti-inflammatory drugs, yes/no / Наличие БПВП, да/нет & $0.16^{*}$ & $0.16^{*}$ \\
\hline Leukocytes, 109 / / Лейкоциты, 109/л & $0.19 * *$ & $0.23^{* *}$ \\
\hline Platelets, 109/I / Тромбоциты, 109/л & $0.15^{*}$ & $0.20 * *$ \\
\hline $\mathrm{CRP}, \mathrm{mg} / \mathrm{l} / \mathrm{CPБ}, \mathrm{M \Gamma} / \mathrm{л}$ & $0.18^{* *}$ & $0.22^{* *}$ \\
\hline ESR, $\mathrm{mm} / \mathrm{h} / \mathrm{CO}, \mathrm{MM} / 4$ & $0.13^{*}$ & $0.16^{*}$ \\
\hline \multicolumn{3}{|c|}{ 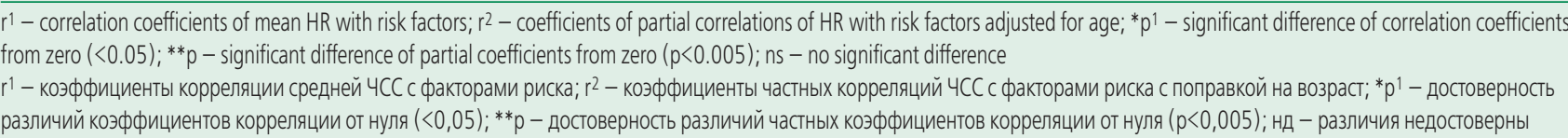 } \\
\hline
\end{tabular}

age, accelerated HR in RA is directly associated only with an increased joint functional disability index, HAQ, RA severity index, the level of inflammatory markers and leflunomide intake.

In accordance with mean values of HR RA patients were split into quintiles. Mean values and the incidence of clinical, instrumental and laboratory indices of women from quintile 1 and 5 were compared (Table 5). After adjustment for age, it was established that the patients with mean $\mathrm{HR} \geqslant 86$ beats per min (corresponds to the lower border of quintile 5 ) versus RA patients with $H R \leqslant 71$ beats per min (corresponds to the upper border of quintile 1) had lower levels of TCh and LDLC in blood serum, higher concentration of inflammatory markers (leukocytes, CRP, ESR), platelets, pain by VAPS, RA activity index (DAS 28), HAQ, severity index, the age of commencement of glucocorticoid (GC) therapy. Correlations of mean HR with the level of TCh and LDLC lost their significance after adjustment for the level of CRP $(r=0.1 ; p>0.1)$. Besides, in this group the occurrence of patients with RA duration over 12 months, radiological stage III/IV, extra-articular manifestations of RA was higher. In women with RA with $H R \geqslant 86$ beats per min, left ventricular diastolic dysfunction (LVDD) was recorded more often as well, although no significant differences in the frequency of функциональной недостаточности суставов HAQ, индекса тяжести РА, уровня воспалительных маркеров и приёмом лефлуномида.

Согласно величинам средней ЧСС пациентки с РА были разбиты на квинтили. Сравнивали средние величины и частоту встречаемости клинико-инструментальных и лабораторных показателей женщин из 1 и 5 квинтилей (табл. 5). При поправке на возраст установлено, что пациентки со значениями средней чСС $\geqslant 86$ уд/мин (соответствует нижней границе 5 квинтиля) отличались от больных РА с чСС $\leqslant 71$ уд/мин (соответствует верхней границе 1 квинтиля) более низким содержанием ОХС и ХC лПнП в сыворотке крови, более высокой концентрацией воспалительных маркеров (лейкоциты, СРБ, СОЭ), тромбоцитов, боли по ВАШ, индексу активности PA (DAS 28), HAQ, индекса тяжести, возрастом начала терапии глюкокортикоидами (ГК). Корреляции средней ЧСС с уровнем OXС и XС ЛПНП теряли свою значимость при коррекции по уровню СРБ $(r=0,1 ; p>0,1)$. Кроме того, в данной группе была выше частота встречаемости пациенток с длительностью РА>12 мес, III/IV рентгенологической стадией, системными проявлениями РА. У женщин с РА со значениями чСС $\geqslant 86$ уд/мин также чаще регистрировалась диастолическая дисфункция левого желудочка (ДДФ Лж), хотя значимых различий по частоте выявления гипертрофии левого желудочка, размерам полостей серд- 
Table 5. Comparison of clinical and laboratory parameters in RA women with mean HR $\mathbf{7 1}$ beats per min (quintile 1) and mean $\mathrm{HR} \geq 86$ beats per min (quintile 5)

Таблица 5. Сравнение клинико-лабораторных параметров у женщин с РА со средней ЧСС $\leq 71$ уд/мин (1 квинтиль) и средней ЧСС $\geq 86$ уд/мин (5 квинтиль)

\begin{tabular}{|c|c|c|c|}
\hline Indicators / Показатели & $\begin{array}{c}\text { Mean HR } \leqslant 71 \text { beats per min (quintile } 1) / \\
\text { Средняя ЧСС } \leqslant 71 \text { уд/мин (1 квинтиль) (n=61) }\end{array}$ & $\begin{array}{c}\text { Mean HR } \geqslant 86 \text { beats per min (quintile 5) / } \\
\text { Средняя ЧСС } \geqslant 86 \text { уд/мин (5 квинтиль) ( }=62 \text { ) }\end{array}$ & $p$ \\
\hline TCh, mmol/l / ОХС, ммоль/л & $5.84 \pm 0.13$ & $5.11 \pm 0.17$ & 0.001 \\
\hline LDLC, mmol/I / ХС ЛНП, ммоль/л & $4.06 \pm 0.13$ & $3.28 \pm 0.18$ & 0.001 \\
\hline Leukocytes, 109/I / Лейкоциты, 109/л & $7.49 \pm 0.25$ & $9.75 \pm 0.50$ & $<0.001$ \\
\hline Platelets, 109/I / Тромбоциты,109/л & $317.81 \pm 2.5$ & $437.7 \pm 31.3$ & $<0.001$ \\
\hline $\mathrm{CRP}, \mathrm{mg} / \mathrm{l} / \mathrm{CPБ}, \mathrm{Mг} / \mathrm{л}$ & $24.7 \pm 3.53$ & $44.4 \pm 7.03$ & 0.006 \\
\hline $\mathrm{ESR}, \mathrm{mm} / \mathrm{h} / \mathrm{CO}, \mathrm{Mm} / \mathrm{4}$ & $33.9 \pm 2.7$ & $43.9 \pm 23.5$ & 0.025 \\
\hline 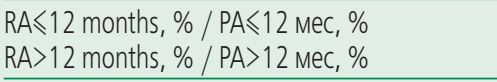 & $\begin{array}{l}15 \\
85 \\
\end{array}$ & $\begin{array}{c}2 \\
98 \\
\end{array}$ & 0.036 \\
\hline $\begin{array}{l}\text { Extra-articular manifestations of RA, \% / } \\
\text { Системные проявления, \% }\end{array}$ & 26 & 47 & 0.025 \\
\hline VAPS / ВАШ боли & $47.8 \pm 2.6$ & $60.1 \pm 2.7$ & 0.002 \\
\hline $\begin{array}{l}\text { Radiological stage III/IV,\% / } \\
\text { Рентген стадия III/IV, \% }\end{array}$ & 42 & 69 & 0.003 \\
\hline HAQ, points / HAQ, баллы & $1.30 \pm 0.09$ & $1.65 \pm 0.11$ & 0.002 \\
\hline DAS28, points / DAS28, баллы & $5.42 \pm 0.18$ & $5.94 \pm 0.19$ & 0.029 \\
\hline Severity index, points / Индекс тяжести, баллы & $4.71 \pm 0.29$ & $6.92 \pm 0.52$ & $<0.001$ \\
\hline $\begin{array}{l}\text { Age of GC therapy commencement, years / } \\
\text { Возраст начала ГК, лет }\end{array}$ & $42.3 \pm 2.03$ & $32.8 \pm 2.9$ & 0.008 \\
\hline LVDD, \% / ДДФ ЛЖ, \% & 22 & 50 & 0.002 \\
\hline
\end{tabular}

left ventricular hypertrophy and dimensions of cardiac chambers were revealed (Table 5). Consequently, the patients with $\mathrm{HR} \geqslant 86$ beats per min are characterized by higher activity and severity of RA and more frequent LVDD.

\section{Discussion}

The results of our study show that women with RA without clinical signs of CVD as compared with women without rheumatic diseases have higher values of minimum and mean HR according to 24-h ECG after adjustment for all main TRF for CVDs. Convincing data on association between tachycardia and unfavorable course of CVD have been received by now. $\mathrm{HR}$ is proved to be an independent predictor of development and complicated course of IHD, CHF and other CVDs $[8-15,25,26]$. In these studies all-causes mortality risk increased significantly in subjects with resting HR over 84 beats per min. Mortality in patients with HR from 90 to 99 beats per min was three times as high as with HR less than 60 beats per min [9-15]. According to the data of the British Regional Heart Study [13] HR>90 beats per min is an independent predictor of development of sudden cardiac death in middle-aged people without clinical signs of IHD. The results of Russian Register data analysis conducted by Shalnova S.A., et al. have demonstrated that women ца выявлено не было (табл. 5). Таким образом, пациентки с ЧСС $\geqslant 86$ уд/мин характеризуются более высокой активностью, тяжестью РА и более высоким процентом выявления ДДФ ЛЖ.

\section{Обсуждение}

По результатам нашего исследования женщины с РА без клинических признаков ССЗ отличаются от женщин без ревматических заболеваний более высокими значениями минимальной и средней ЧСС по данным ХМ-ЭКГ с учётом поправки на все основные ТФР ССЗ. В настоящее время получены убедительные данные о связи между тахикардией и неблагоприятным течением ССЗ. Доказано, что ЧСС является независимым предиктором развития и осложнённого течения ИБС, ХСН и других ССЗ [8-15,25,26]. В этих исследованиях риск смерти от всех причин резко возрастал у лиц с ЧСС в покое более 84 уд/мин. Летальность у больных с ЧСС от 90 до 99 уд/мин была в три раза выше, чем у лиц с ЧСС менее 60 уд/мин [9-15]. По данным исследования British Regional Heart Study [13] ЧСС>90 уд/мин является независимым предиктором развития внезапной сердечной смерти у лиц среднего возраста без клинических признаков ИБС. Результаты анализа данных российского регистра, проведенного Шальновой С.А. и соавт. продемонстрировали, что женщины с ЧСС более 80 уд/мин имели значимо более высокий риск как общей [относительный риск (ОР) 1,30; доверительный интервал (ДИ) 
with HR over 80 beats per min had significantly higher risk of both all-cause mortality [Relative Risk (RR) 1.30; Confidence Interval (CI) 1.05-1.61] and cardiovascular mortality (RR 1.63; Cl 1.19-2.34) as compared with women whose HR was lower than 60 beats per min after adjustment for TRF for CVD [25]. According to Copie X. et al. [26] data, HR assessed during 24-h ECG in patients with CHF has higher prognostic significance in CVE development than the left ventricular ejection fraction (LVEF). Among the mechanisms explaining the association between high $\mathrm{HR}$ and CVD, the main role is played by increased sympathetic activity [27]. Chronic hypersympathicotonia promotes the development and maintenance of $\mathrm{AH}$, myocardial ischemia, heart rhythm disorders, accelerates vascular remodeling and left ventricular hypertrophy, plays the central role in progression of $\mathrm{CHF}$ and may result in sudden cardiac death. Besides, tachycardia may directly decrease ventricular fibrillation threshold or be a marker of a low threshold of fibrillation in patients with IHD and other myocardial diseases, that are responsible for increased risk of sudden cardiac death. HR is one of hemodynamic components of mechanical stress on the arterial wall.

In our study, the main factors associated with higher HR in women with RA were the parameters reflecting disease severity (a high level of inflammatory markers, duration and activity of disease, extra-articular manifestations, a high joint functional disability index and severity index) that may confirm the role of RA-related factors in an increased cardiovascular risk. It has been proved earlier that disease severity plays an important role in development of CVE in RA and is characterized by high joint scores, extra-articular manifestations, joint functional disability intensity, the presence of rheumatoid factor/cyclic citrullinated peptide antibodies and increased level of inflammatory markers (ESR, CRP) [28-34]. We have also shown that mean HR is significantly higher at leflunomide intake than at intake of other BAIDs (methotrexate, sulfasalazine, hydroxychloroquine). The use of leflunomide in RA is known to be associated with lower probability of CVE ( $R R=0.59)$ [35], however the risk is twice as high as at methotrexate therapy [36], conditioned probably by the capacity of the medication to induce AH [36]. Increased sympathetic activation during the use of leflunomide is considered to be one of possible mechanisms of AH development [37].

According to the results of our study, no association between mean HR and main TRF for CVD and carotid arteries atherosclerotic lesion was revealed. Noteworthy the negative correlation between mean $\mathrm{HR}$ and the level of SBP and DBP, as well as lower values of TCh and LDLC in RA patients with mean HR
1,05-1,61], так и сердечно-сосудистой смертности (ОР 1,63 ; дИ 1,19-2,34) по сравнению с женщинами, ЧСС которых была менее 60 уд/мин, с поправкой на ТФР ССЗ [25]. По данным Copie X. и соавт. [26] ЧСС, оцениваемая при ХМ-ЭКГ, у больных ХCH имеет более высокое прогностическое значение для возникновения ССО, чем фракция выброса ЛЖ. Среди механизмов, объясняющих взаимосвязь высокой ЧСС и ССЗ, основная роль отводится повышенной симпатической активности [27]. Хроническая гиперсиматикотония способствует развитию и поддержанию АГ, ишемии миокарда, нарушений ритма сердца, ускоряет процессы сосудистого ремоделирования и гипертрофии левого желудочка, играет центральную роль в прогрессировании XСН и может привести к внезапной сердечной смерти. Кроме того, тахикардия может прямо понижать порог фибрилляции желудочков или быть маркером низкого порога фибрилляции у больных ИБС и другими поражениями миокарда, с чем и связывают повышенный риск внезапной сердечной смерти. ЧСС является одним из гемодинамических компонентов механического стресса артериальной стенки.

В нашем исследовании основными факторами, ассоциирующимися с увеличением ЧСС у женщин с РА стали параметры, отражающие тяжесть заболевания (высокий уровень воспалительных маркеров, длительность и активность болезни, наличие внесуставных проявлений, высокий индекс функциональной недостаточности суставов и индекс тяжести), что может подтверждать роль РА-связанных факторов в увеличении кардиоваскулярного риска. Ранее было доказано, что важную роль в развитии ССО при РА играет тяжесть заболевания, характеризующаяся высоким суставным счётом, наличием внесуставных проявлений, выраженностью функциональной недостаточности суставов, наличием ревматоидного фактора/антител к циклическому цитруллиновому пептиду и высоким уровнем маркеров воспаления (СОЭ, СРБ) [28-34]. Нами также показано, что средняя ЧСС значимо выше на фоне приема лефлуномида, чем на фоне применения других БПВП (метотрексата, сульфасалазина, гидроксихлорохина). Известно, что использование лефлуномида при РА ассоциируется со снижением вероятности ССО $(\mathrm{OP}=0,59)$ [35], однако риск в 2 раза выше, чем при лечении метотрексатом [36], что может быть обусловлено способностью препарата вызывать АГ [36]. К одному из возможных механизмов развития АГ при использовании лефлуномида относят увеличение симпатической активации [37].

По результатам нашего исследования не выявлено взаи мосвязи между средней ЧСС и основными ТФР ССЗ, наличием атеросклеротического поражения сонных артерий. Обращает на себя внимание обратная корреляция средней ЧСС с уровнем САД и ДАД, а также более низкие значения ОХС и ХС ЛПНП у больных РА со средней ЧСС в пределах пятого квинтиля по сравнению с уровнем таковых у женщин с 
within the limits of quintile 5 as compared with the level of the same characteristics in women with HR within the limits of quintile 1 . The level of CRP almost completely explained the connection between BP, blood lipid profile indicators and HR. These results add to the hypothesis of association between low lipid level and high risk of CVD and mortality in RA. Myasoedova E.E. et al. have demonstrated a paradoxical association of lipid level with CVD risk; lower levels of TCh and LDLC correlate with a higher risk of unfavorable cardiovascular events in RA patients. At that, CVD risk was significantly higher in case of increased inflammatory activity (in particular when ESR $>30 \mathrm{~mm} / \mathrm{h}$ ) [38]. It should be noted that the incidence of LVDD was almost 2.5 times greater in women with HR in quintile 5 as compared with this characteristic in quintile 1 , what is likely to be related to more serious course of disease in this group of patients or with a direct damaging effect of high HR on the myocardium.

The limitation of our study is its single-step nature that does not allow to reveal cause and effect relationship between increased HR and TRF for CVD, structural and functional changes in the heart and vessels, as well as RA severity. Furthermore, prospective studies should be conducted with assessment of "steady" end-points to specify the role of high HR as a risk factor for development of CVD in women with RA.

\section{Conclusion}

Thus, in women with RA higher mean HR according to 24-h ECG is associated with activity and severity of rheumatoid inflammation. In women with RA with mean $H R \geqslant 86$ beats per min, left ventricular diastolic dysfunction is determined more often as compared with patients with mean HR $\leqslant 71$ beats per min. Taking into consideration our data prospective studies should be conducted to determine the role of accelerated HR as a risk factor for development of CVD and the feasibility of preventive measures creation targeted to lower HR to prevent CVE in RA.

Disclosures. All authors have not disclosed potential conflicts of interest regarding the content of this paper.
ЧСС в пределах первого квинтиля. Уровень СРБ практически полностью объяснял связь АД, показателей липидного спектра крови и ЧСС. Эти результаты дополняют гипотезу об ассоциации низкого уровня липидов С высоким риском ССЗ и смертности при РА. Мясоедовой Е.Е. и соавт. продемонстрирована парадоксальная ассоциация уровня липидов С риском ССЗ: более низкие уровни ОХС и ХС ЛПНП коррелируют с повышением риска неблагоприятных кардиоваскулярных событий у больных РА. При этом риск ССЗ существенно повышался с нарастанием воспалительной активности (в частности, при увеличении СОЭ> 30 мм/ч) [38]. Важно отметить, что частота ДДФ ЛЖ была почти в 2,5 раза выше у женщин с ЧСС в пятом квинтиле, по сравнению с данным показателем в первом квинтиле, что, возможно, связано с более тяжелым течением болезни в данной группе больных, либо с прямым повреждающим действием высокой ЧСС на миокард.

Ограничением нашего исследования является его одномоментный характер, что не позволяет выявить причинно-следственные связи между увеличением ЧСС и ТФР ССЗ, структурно-функциональными изменениями сердца и сосудов, а также тяжестью РА. Кроме того, необходимо проведение проспективных исследований с оценкой «твердых» конечных точек для уточнения роли повышенной ЧСС как фактора риска развития ССЗ у женщин с РА.

\section{Заключение}

Таким образом, у женщин с РА увеличение средней ЧСС по данным суточного мониторирования ЭКГ ассоциируется с активностью и тяжестью ревматоидного воспаления. У женщин с РА со значениями средней ЧСС $\geqslant 86$ уд/мин чаще регистрируется диастолическая дисфункция миокарда ЛЖ по сравнению с пациентками со значениями средней чсс $\leqslant 71$ уд/мин. Полученные нами данные диктуют необходимость проведения проспективных исследований для определения роли повышенной ЧСС как фактора риска развития ССЗ и целесообразности разработки профилактических мероприятий, направленных на снижение ЧСС с целью предотвращения ССО при РА.

Конфликт интересов. Авторы не сообщили об отсутствии потенциального конфликта интересов по данной статье. 


\section{References / Литература}

1. Meune C., Touze E., Trinqurte L., Allanore Y. Trends in cardiovascular mortality in patients with rheumatoid arthritis over 50 years: a systematic review and meta-analysis of cohort studies. Rheumatology 2009:48:1309-13.

2. Meune C., Touzé E., Trinquart L., Allanore Y. High risk of clinical cardiovascular events in RA: levels of associations of myocardial infarction and stroke through a systematic review and meta-analysis. Arch Cardiovasc Dis 2010;103:253-61.

3. Crowson C.S., Gabriel S.E. Towards improving cardiovascular risk management in patients with rheumatoid arthritis: the need for accurate risk assessment. Ann Rheum Dis 2011;70(5):719-21.

4. Leuven S.I., Franssen R., Kastelein J.J. et al. Systemic inflammation as a risk factor for atherothrombosis. Rheumatology 2008;47:3-7.

5. Koopman F.A., Stoof S.P., Straub R.H. et al. Restoring the balance of the autonomic nervous system as an innovative approach to the treatment of rheumatoid arthritis. Mol Med 2011;17(9-10):937-48.

6. Novikova DS, Popkova TV, Markelova El et al. Clinical significance of the assessment of cardiac rhythm variability in patients with rheumatoid arthritis. Klin Med (Mosk) 2009;87(1):27-32. Russian (Hoвикова Д.С., Попкова Т.В., Маркелова Е.И. и соавт. Клиническое значение оценки вариабельности ритма сердца у больных ревматоидным артритом. Клиническая медицина 2009;1:27-32).

7. Anichkov D.A., Platonova A.A. Clinical significance of heart rate variability indexes derived from 5-minute and 24-hour ECG recordings in patients with rheumatoid arthritis. Rational Pharmacother. Card. 2009; (1):77-82. Russian (Аничков Д.А., Платонова А.А. Клиническое значение показателей вариабельности сердечного ритма (по данным 5-минутных и 24-часовых записей ЭКГ) у больных ревматоидным артритом. РФК 2009;(1):77-82).

8. Cook S., Togni M., Schaub M. et al. High heart rate: a cardiovascular risk factor? Eur Heart J 2006;27:2387-93

9. Goldberg R.J., Larson M., Levy D. Factors associated with survival to 75 years of age in middle-aged men and women. The Framingham Study. Arch Intern Med 1996;156:505-10.

10. Schwartz R.J. The neural control of heart rate and risk stratification after myocardial infarction. Eur Heart J 1999;1(Suppl H):H33-H43.

11. Dyer A.R., Persky V., Stamler J. et al. Heart rate as a prognostic factor for coronary heart disease and mortality: findings in three Chicago epidemiologic studies. Am J Epidemiol 1980;112:736-49.

12. Kannel W.B., Kannel C., Paffenbarger R.S. et al. Heart rate and cardiovascular mortality: the Framingham study. Am Heart J 1987;113:1489-94.

13. Wannamethee G., Shaper A.G., Macfarlane P.W. et al. Risk factors for sudden cardiac death in middle-aged British men. Circulation 1995;91:1749-56.

14. Gillum R., Makus D., Feldman J. Pulse rate, coronary heart disease, and death: the NHANES I epidemiologic follow-up study. Am Heart J 1991;121:172-7.

15. Aronow W., Ahn C., Mercando A., Epsteim S. Association of average heart rate on 24-hour ambulatory electrocardiograms with incidence of new coronary events at 48-month follow-up in $1311 \mathrm{pa}$ tients (mean age 81 years) with heart disease and sinus rhythm. Am J Cardiol 1996;78:1175-6.

16. Sajadieh A., Nielsen O., Rusmussen V. et al. Increased heart rate and reduced heart rate variability are associated with subclinical inflammation in middle-age and elderly subjects with no apparent heart diseases. Eur Heart J 2004;25:363-70.

17. Arnett F.C., Edworthy S.M., Bloch D.A. The ARA 1987 revised criteria for classification of rheumatoid arthritis. Arthritis Rheum 1988:31:315-24.

18. Rheumatoid arthritis. Q: Nasonov EL, editor. Clinical recommendations. Rheumatology. Moscow: GEOTAR-Media; 2010: 25-72. Russian (Rheumatoid arthritis. B: Насонов Е.Л., редактор. Клинические рекомендации. Ревматология. М.: ГЭОТАР-Медиа; 2010: 25-72).

19. De BackerG., Ambrosioni E., Borch-Johnsen K. et al. Third Joint Force of European and other Societies on Cardiovascular Disease and Prevention in Clinical Practice. European guidelines on cardiovascular disease and prevention in clinical practice. Atherosclerosis 2003;171:145-55.

20. Haward G., Sharrett A.R., Heiss G. et al. Carotid artery intima-media thickness distribution in general populations as evaluated by B-mode ultrasound. Stroke 1993;24:1297-1304
21. National guidelines for diagnosis and treatment of hypertension (4th revision). Sistemye Gipertenzii 2010; (3):5-26. Russian (Национальные рекомендации по диагностике и лечению артериальной гипертонии (четвертый пересмотр). Системные гипертензии 2010; (3): 5-26).

22. National guidelines for diagnosis and treatment of chronic heart failure. Serdechnaya Nedostatochnost' 2010;11 (1): 1-45. Russian (Национальные рекомендации по диагностике и лечению хронической сердечной недостаточности. Сердечная недостаточность 2010;11 (1): 1-45).

23. Gerasimov A.N. Meditsinskaya statistika. Moscow: Meditsinskoe informatsionnoe agentstvo; 2007. Russian (Герасимов А.Н. Медицинская статистика. М.: Медицинское информационное агентство; 2007)

24. Cramer H. Mathematical Methods of Statistics (PMS-9). Princeton: Princeton University Press; 1999.

25. Shal'nova SA, Deev AD, Oganov RG et al. Pulse rate and cardiovascular mortality of men and women in Russia. Results of epidemiological studies. Kardiologiia 2005;45(10):45-50. Russian (Шальнова С.А., Деев А.Д., Оганов Р.Г. и др. Частота пульса и смертность от сердечно-сосудистых заболеваний у российских мужчин и женщин. Результаты эпидемиологического исследования. Кардиология 2005;(10):45-50).

26. Copie X., Hnatkova K., Staunton A. et al. Predictive power of increased heart rate versus depressed left ventricular ejection fraction and heart rate variability for risk stratification after myocardial infarction. J Am Coll Cardiol 1996; 27:270-6

27. Palatini P., Julius S. Heart rate and cardiovascular risk. J Hypertens 1997:15:3-17.

28. Goodson N.J., Symmons D.P., Scott D.G., Bunn D., Lunt M., Silman A.J. Baseline levels of C-reactive protein and prediction of death from cardiovascular disease in patients with inflammatory polyarthritis: a ten-year follow up study of a primary care-based inception cohort. Arthritis Rheum 2005; 52:2293-9.

29. Poole C.D., Conway P., Currie C.J. An evaluation of the association between C-reactive protein, the change in $\mathrm{C}$-reactive protein over one year, and all-cause mortality in chronic immune-mediated in flammatory disease managed in UK general practice. Rheumatology (Oxford) 2009; 48:78-82.

30. Jacobsson L.T., Turesson C., Hanson R.L. et al. Joint swelling as a predictor of death from cardiovascular disease in a population study of Pima Indians. Arthritis Rheum 2001; 44:1170-6.

31. Wållberg-Jonsson S., Johansson H., Ohman M.L., Rantapää-Dahlqvist S. Extent of inflammation predicts cardiovascular disease and overall mortality in seropositive rheumatoid arthritis. A retrospective cohort study from disease onset. J Rheumatol 1999; 26:2562-71.

32. Rho Y.H., Chung C.P., Oeser A, et al. Inflammatory mediators and premature coronary atherosclerosis in rheumatoid arthritis. Arthritis Rheum 2009;15;61:1580-5.

33. Goodson N.J., Wiles N.J., Lunt M., Barrett E.M., Silman A.J., Symmons D.P. Mortality on early inflammatory arthritis: cardiovascular mortality in seropositive patients. Arthritis Rheum 2002;46:2010-9.

34. López-Longo F.., Oliver-Miñarro D., de la Torre I. et al. Association between anti-cyclic citrullinated peptide antibodies and ischemic heart disease in patients with rheumatoid arthritis. Arthritis Rheum 2009:61:419-24

35. Naranjo A., Sokka T., Descalzo M.A. et al.; QUEST-RA Group. Cardiovascular disease in patients with rheumatoid arthritis: results from the QUEST-RA study. Arthr Res Ther 2008;10(2):R30.

36. Solomon D.H., Avorn J., Katz J.N. Immunosuppressive medications and hospitalization for cardiovascular events in patients with rheumatoid arthritis. Arthr Rheum 2006;54:3790-8.

37. Rozman B., Praprotnik S., Logar D. et al. Leflunomide and hypertension. Ann Rheum Dis 2002;61:5679.

38. Myasoedova E., Crowson C.S., Kremers H.M.et al. Lipid paradox in rheumatoid arthritis: the impac of serum lipid measures and systemic inflammation on the risk of cardiovascular disease. Ann Rheum Dis 2011;70(3):482-7.

Received / Поступила: 03.10.2012 Accepted / Принята в печать: 15.10.2012 